\begin{abstract}
Iranica
Abstracta Iranica Revue bibliographique pour le domaine irano-aryen

Volume 34-35-36 | 2017

Comptes rendus des publications de 2011-2013
\end{abstract}

\title{
Aren M. Maeir (ed.). Tell es-Safi/Gath I: The 1996-2005 Seasons
}

\section{Astrid Nunn}

\section{(2) OpenEdition}

Journals

Édition électronique

URL : http://journals.openedition.org/abstractairanica/41619

DOI : 10.4000/abstractairanica.41619

ISSN : 1961-960X

Éditeur :

CNRS (UMR 7528 Mondes iraniens et indiens), Éditions de l'IFRI

Référence électronique

Astrid Nunn, «Aren M. Maeir (ed.). Tell es-Safi/Gath I: The 1996-2005 Seasons », Abstracta Iranica [En ligne], Volume 34-35-36 | 2017, document 55, mis en ligne le 15 juillet 2016, consulté le 26 septembre 2020. URL : http://journals.openedition.org/abstractairanica/41619 ; DOI : https://doi.org/10.4000/ abstractairanica.41619

Ce document a été généré automatiquement le 26 septembre 2020.

Tous droits réservés 


\section{Aren M. Maeir (ed.). Tell es-Safi/Gath I: The 1996-2005 Seasons}

\section{Astrid Nunn}

\section{RÉFÉRENCE}

Aren M. Maeir (ed.). Tell es-Safi/Gath I: The 1996-2005 Seasons. Vol. I: Text, vol. II: Plates, Wiesbaden, Harrassowitz Verlag, 2012. (Ägypten und Altes Testament 69)

1 Les fouilles sur le site de Tell es-Safi (plaine de la shéphélah), communément identifié à la cité philistine de Gath, ont été reprises en 1996. L'époque la mieux représentée est celle du Fer II. La cité fut détruite au VIII ${ }^{\mathrm{e}}$ s. par les Assyriens et perdit de son importance, tout en continuant à être habitée. L'époque achéménide est représentée par quelques murs et les objets d'une (fameuse) 'favissa' découverte par F. J. Bliss et R. A. S. Macalister et publiée en 1902 qui pourrait indiquer l'existence d'un temple (p. 56). Un scarabée phénicien du groupe de Tharros (VI $\mathrm{IV}^{\mathrm{e}} \mathrm{s}$. av. J.-C.) et représentant Héraclès a été rapporté par des paysans aux fouilleurs (p. 464).

\section{AUTEURS}

\section{ASTRID NUNN}

Université de Munich 